\title{
ВЗАЕМОЗВ'ЯЗОК МІЖ ПСИХОФІЗІОЛОГІЧНИМИ ОСОБЛИВОСТЯМИ СТУДЕНТІВ ТА ЇХ УСПІШНІСТЮ ПРИ ДИСТАНЦЙНІЙ ФОРМІ НАВЧАННЯ
}

\author{
С. О. Коноваленко, Р. М. Гнатюк, Л. В. Татарчук \\ ДВНЗ “Тернопільський державний медичний університет \\ імені I. Я. Горбачевського МОЗ Украӥни”
}

\section{CORRELLATION BETWEEN PSYCHOPHYSIOLOGICAL PECULIARITIES OF STUDENTS AND THEIR PROGRESS IN STUDIES AT DISTANCE EDUCATIONAL PROGRAM}

\author{
S. O. Konovalenko, R. M. Hnatiuk, L. V. Tatarchuk \\ SHEI "Ternopil State Medical University by I. Ya. Horbachevsky of MPH of Ukraine"
}

\begin{abstract}
Досліджена успішність студентів медичного університету з нормальної фізіології, мікробіології, вірусології та імунології, клінічної фармакології з рецептурою при дистанційній формі навчання. Встановлено, що особам 3 домінуванням правої півкулі головного мозку (ліворукі) важче дається засвосння навчального матеріалу порівняно $з$ праворукими.

The article presents the analysis of medical students' progress in studies of Normal Physiology, Microbiology, Virology and Immunology, and Clinical Pharmacology in distance educational program. It was found out that individuals with the dominance of the right hemisphere of the brain (left-handed) demonstrate difficulties in mastering the study materials if compared to the right-handed ones.
\end{abstract}

Вступ. Відомо, що процеси інтеграції в сучасному світі розширюються та охоплюють все більше сфер життедіяльності людини. Освіта в Україні в цілому і особливо медична освіта не можуть існувати поза межами європейської інтеграції. Останньому сприяє Болонська система, яка передбачає забезпечення якісної освіти та підготовку висококваліфікованих спеціалістів. Світовий процес переходу до інформаційного суспільства, а також економічні, політичні і соціальні зміни, які відбуваються в Україні, зумовлюють необхідність прискорення реформування системи освіти. Перш за все це стосується задоволення освітніх потреб громадян протягом всього життя, забезпечення доступу до освітньої і професійної підготовки всіх, хто має необхідні здібності і адекватну підготовку. 3 іншого боку, завдяки мережі Internet потік інформації звідусіль настільки великий, що освоїти іiі неможливо. На допомогу приходить on-lineосвіта (дистанційне навчання), яка концентрує у собі найголовніше з тієї чи іншої сфери життя суспільства [1]. Широке розповсюдження та впровадження комп’ютерних технологій у навчальний процес суттєво його інтенсифікує, розвиває ініціативність, елементи творчості, самостійності у студентів при вирішенні (c) С. О. Коноваленко, Р. М. Гнатюк, Л. В. Татарчук нестандартних завдань та виконанні науково-дослідних робіт, дає можливість систематично звертатися за додатковою і необхідною для навчання інформацією, не перериваючи виконання основного завдання. Варто також вказати, що при цьому не завжди враховуються психофізіологічні особливості студентів, які відіграють важливу роль у повноцінному засвоєнні матеріалу $[2,3]$. Враховуючи наведене, метою даної роботи стало вивчення взаємозв'язку між психофізіологічними особливостями студентів та їх успішністю при дистанційній формі навчання.

Основна частина. Для оцінки ефективності засвоєння навчального матеріалу з нормальної фізіології, мікробіології, вірусології та імунології, клінічної фармакології з рецептурою проведений педагогічний експеримент, в якому взяли участь 192 студенти, які освоювали вказані предмети дистанційно. Вони були розділені на 2 групи. В 1-шу групу ввійшли праворукі студенти (“правші”), у 2-гу - студенти, у яких домінуючою була ліва рука (“лівші”). Більшість дослідників стверджує, що у праворуких людей домінує ліва півкуля головного мозку, а у ліворуких - права. При визначенні праворукості або ліворукості використаний Луганський сенсибілізований опитувальник для 
визначення ліворукості у дітей $[4,5,6]$.Серед досліджених студентів праворуких виявилося 167, що склало $87,0 \%$, а ліворуких - 25 (13,0\%).

Ефективність засвоєння навчального матеріалу оцінювали за результатами поточної успішності студентів. Оцінювання проводили за дванадцятибальною системою. При цьому аналізували середній бал, питому вагу відмінних, добрих, задовільних та незадовільних оцінок, а також загальну та якісну успішність. Отримані цифрові величини обробляли статистично. Різницю між порівнювальними величинами визначали за коефіцієнтом Стьюдента [7]. Отримані результати представлені в таблиці 1. Усестороннім аналізом представлених даних встановлено, що середній бал поточної успішності з мікробіології, вірусології та імунології у 1-й групі студентів (студенти з домінуванням лівої півкулі головного мозку -

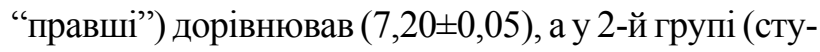

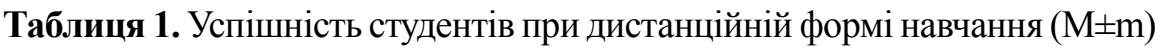

\begin{tabular}{|c|c|c|c|}
\hline № за/п & Навчальний предмет & $\begin{array}{c}1 \text {-ша група } \\
\text { (12-бальне } \\
\text { оцінювання) }\end{array}$ & $\begin{array}{c}2 \text {-га група } \\
(12 \text {-бальне } \\
\text { оцінювання) }\end{array}$ \\
\hline 1 & Мікробіологія, вірусологія та імунологія & $7,20 \pm 0,05$ & $6,80 \pm 0,03 * *$ \\
\hline 2 & Нормальна фізіологія & $7,00 \pm 0,04$ & $6,70 \pm 0,03 * *$ \\
\hline 3 & Клінічна фармакологія з рецептурою & $7,40 \pm 0,06$ & $7,10 \pm 0,05^{*}$ \\
\hline
\end{tabular}

Примітка. Зірочкою позначені величини, що статистично достовірно відрізняються від аналогічних 1-ї групи (* - $<<0,05$; $* *-\mathrm{P}<0,01)$.

денти з домінуванням правої півкулі головного мозку

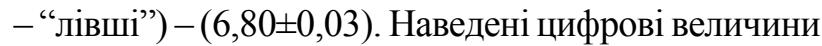
статистично достовірно ( $<<0,01)$ відрізнялися між собою, і останній показник виявився меншим за попередній на 5,55 \%. Встановлено також, що у студентів 1-ї групи при аналізі поточної успішності більшою була питома вага відмінних та добрих оцінок порівняно з аналогічними показниками 2-ї групи. Так, у 1-й групі студентів кількість відмінних та добрих оцінок складала $(85,00 \pm 0,45) \%$, а у 2-й групі (лівші) - $(76,0 \pm 1,2) \%$. Між наведеними показниками виявлена статистично достовірна різниця ( $<<0,01)$. При цьому перша цифрова величина перевищувала останню на 9,0 \%. Варто також зазначити, що кількість негативних оцінок у 1-й групі спостережень була на 12,4 \% меншою порівняно із студентами, у яких домінувала права півкуля головного мозку. Отримані показники свідчать, що успішність студентів з домінуванням лівої півкулі головного мозку значно краща порівняно із студентами, у яких спостерігалося переважання правої півкулі головного мозку.

Майже аналогічні дані отримані при порівнянні успішності 1-ї та 2-ї груп студентів при вивченні та засвоєнні навчального матеріалу з нормальної фізіології та клінічної фармакології з рецептурою. Так, середній бал з нормальної фізіології у праворуких студентів дорівнював $(7,00 \pm 0,04)$, а у ліворуких $-(6,70 \pm 0,03)$. При цьому останній показник виявився меншим за попередній на 4,3 \% і статистично достовірно $(\mathrm{P}<0,01)$ від нього відрізнявся. Середній бал поточної успішності з клінічної фармакології з рецептурою у 1-й групі спостережень складав $(7,40 \pm 0,06)$, а у 2 -й групі сту- дентів - (7,10 $\pm 0,05)$. Між наведеними цифровими величинами існувала статистично достовірна $(\mathrm{P}<0,05)$ різниця і останній показник був меншим за попередній на 4,05 \%. Отже, отримані результати проведеного дослідження свідчать, що у студентів, де домінувала ліва півкуля головного мозку, поточна успішність виявилася кращою порівняно з ліворукими студентами, тобто останні гірше засвоювали вказані навчальні дисципліни.

Варто також вказати, що в останні роки сучасна педагогіка все частіше звертає увагу на особливості навчання та якість засвоєння навчальних предметів студентами з різними психофізіологічними особливостями, тобто з різним домінуванням півкуль головного мозку. Сьогодні відомо, що психофізіологічні відмінності право- і ліворуких осіб обумовлені різними функціями та домінуванням лівої та правої півкуль головного мозку. Так, ліва півкуля головного мозку, яка домінує у праворуких, відповідає за знакову інформацію (рахунок, читання, мови, ремесло), за здатність аналізувати предмети та явища (розкладати їх на окремі елементи і формувати логічні ланцюжки). Права півкуля мозку, яка домінує у ліворуких осіб, замість наведеного вище аналізу, більш до узагальнення та синтезу, забезпечуючи цілісність сприйняття. Безумовно, що ліва та права півкулі головного мозку функціонують в тісному взаємозв’ язку, проте відносне домінування правої чи лівої півкуль обумовлює тип мислення людини, визначає її характер, темперамент, тривожність, ступінь невротизації, швидкість мислення, пам'ять, здатність концентруватися та інші психофізіологічні особливості $[6,10]$. 
Слід також вказати, що особи з домінуванням лівої руки більш вразливі, збудливі, чутливі порівняно 3 праворукими, проте вони часто невпевнені у собі, схильні до різких змін настрою, у стресових ситуаціях впадають до песимізму та смутку. Для них характерна слабкість вольового контролю і контролю поведінки, їм часто важко стримувати свої емоції, у тому числі й агресивні. Більшість дослідників також вважає, що у ліворуких осіб сигнал для здійснення вирішення тих чи інших завдань, пов' язаних з розумовою діяльністю, є більш пролонгованим [8, 10].

Дистанційне навчання, здійснюване на основі сучасних інформаційних і телекомунікаційних технологій, сприяє ефективному рішенню багатьох проблем навчального процесу. Залишаючись удома, учасник навчального процесу має змогу контактувати з викладачем-модератором, перебуваючи 3 ним на значній відстані. Іншими перевагами є індивідуальний підхід до кожного “учня”, залежно від рівня засвоєння ним програми, та майже повна відсутність особистісного фактора й можливість швидкого доповнення навчального матеріалу новою інформацією. Дистанційна освіта дозволяє безліч нових способів навчання. Студенти мають право вибирати, в числі іншого, як навчатимуться, які матеріали вони використовуватимуть друкарські чи електронні. Час для вивчення матеріалу вибирається студентом самостійно, що дозволяє людині гнучкіше використовувати свій час, значно економити його для інших важливих справ і роботи. При дистанційному навчанні відсутні обмеження відносно часу складання заліків та іспитів. Навчальні матеріали, тести доступні студентові у будь-який час. Він може самостійно вибирати час і об'єм матеріалів, що вивчаються, і за два-три дні інтенсивних занять вивчити і здати дисципліну і навіть скласти іспити за весь семестр. Це особливо вигідно для людей, що вже мають базовий рівень освіти і що вирішили розширити свої знання. Дистанційному навчанню характерна свобода вибору стилю вивчення навчального матеріалу. Зв'язок викладача із студентом відбувається через мережу Інтернет на порталі університету двома основними способами: перший спосіб - обмін інформацією через поштові скриньки, розміщені на Web-пор- талі університету; другий спосіб - зв' язок через Інтернет у системі "Skype".

Отримані результати проведеного педагогічного експерименту та проаналізовані дані літератури свідчать, що ефективне та адекватне засвоєння навчального матеріалу залежить від психофізіологічних особливостей студентів, тобто право-чи ліворукості, що необхідно враховувати при дистанційній формі навчання, Особам з домінуючою лівою рукою нелегко дається те, що пов'язане 3 необхідністю швидкого переключення з одного процесу на інший. У ліворуких тривалий час спостерігаються дисграфія та дислексія.. Останнє слово означає порушення читання, або більш детальніше - часткове порушення процесу читання, яке проявляється у регулярних та систематичних помилках при читанні, що зумовлене несформованістю вищих психічних функцій, які беруть участь у процесах читання. Наведене вище стверджує, що особам з домінуванням правої півкулі головного мозку або нестійкою латералізацією (ліворукі) важче дається засвоєння навчального матеріалу порівняно з праворукими (домінування лівої півкулі головного мозку) та вимагає індивідуальних підходів до студентів для повноцінного засвоєння навчальної дисципліни. Це вимагає від викладачів знати психофізіологічні особливості студентів і враховувати їх при подачі та представленні навчального матеріалу, складанні тестів та екзаменаційних питань і при цьому більше уваги приділяючи ліворуким студентам.

Висновок. Отримані результати проведеного дослідження свідчать, що для адекватного та повноцінного засвоєння навчальної дисципліни при дистанційній формі навчання необхідно враховувати психофізіологічні особливості студентів, тобто право- і ліворукість, створюючи для них відповідну подачу навчального матеріалу на сайтах, адекватні тести та запитання і більше працювати над освоєнням навчальної програми із особами з домінуванням правої півкулі головного мозку. В майбутньому подальше вивчення психофізіологічних особливостей студентів та врахування їх при засвоєнні навчального матеріалу допомагають більш повноцінно опанувати його.

\section{Література}

1. Бут В. Дистанційне навчання - вимога часу / В. Бут // Директор школи. - 2004. - № 1. - С. 28-29.

2. Бизюк А. П. Основы нейропсихологии / А. П. Бизюк. Санкт-Петербург : Речь, 2005.-294 с.

3. Fliesher W. Wartbildung der deutshen Gegenwartssprache /W. Fliesher, I. Barz. - Tubingen : Max Neimeyer Vertag, 1995.

$-382 \mathrm{p}$.

4. Кочерга О. Психофізіологічні особливості діяльності мозку дитини / О. Кочерга // Початкова школа. - 2005. - № 5. - С. $6-8$.

5. Смернова О. А. Таємниця рукості / О. А. Смернова // Гуманітарні науки. - 2001.-№ 2.-С. $105-109$. 
6. Чуприков А. П. Проблеми ліворукості / А. П. Чуприков, Е. А. Волков. - Николаев : Атолла, 2004. - 188 с.

7. Лапач С. Н. Статистические методы в медико-биологических исследованиях Excell / С. Н. Лапач, А. В. Губенко, П. Н. Бабич. -К. : Морион, 2001. - 410 с.

8. Саввін А. О. Дистанційне навчання : сутність та зміст // Педагогіка та психологія : зб. наук. праць Харківського держ. пед. ун-ту ім. Г. С. Сковороди. - Харків, 2001.-Вип. 17.-С.
$21-27$.

9. Чуприков А. П. Асиметрія мозку та ліворукість / А. П. Чуприков, Р. М. Гнатюк, М. А. Чуприкова. - Київ : CMM, 2011.-140 c.

10. Yane M. Loving lefties [How to raise your left-handed child in a right-handed word] / M. Yane. - New York : Pocket Books, 2007. - 178 p. 